\title{
Designing effective female leadership model in governmental organizations
}

\author{
Nosratollah Maleki ${ }^{1}$ and Aryan Askari ${ }^{2 \star}$ \\ ${ }^{1}$ University of Manila, Philippines. \\ ${ }^{2}$ Faculty of Entrepreneurship, University of Tehran, Iran. \\ Accepted $21^{\text {st }}$ August, 2013
}

\begin{abstract}
Since leadership is a critical factor for improving organizational performance, failure or success of an organization highly depends on efficiency of leadership in all levels. Scholars elaborated that leadership is the ability of influencing one's attitudes, aptitudes and beliefs, in the way that it will lead to meet organizational objectives. The main purpose of this study is to consider two domains of efficient leadership and women's leadership style, in order to determine and elaborate the dimensions of the new concept of "Women's Efficient Leadership". We intend to describe the characteristics of women's efficient leadership in state organizations in Iran by means of offering a logical pattern, in order to be able to propose a favorable pattern, leading to increased efficiency in governmental organizations of the country. Innovation of this study can be divided into two parts: one is theoretical contribution and developing the knowledge of efficient leadership as well as women's leadership style, and the second one is scientific contribution and proposing a pattern for women's efficient leadership in state organizations, using compound approach. The outcomes of this study show that women's efficient leadership in state organizations consists of 7 subjects, 17 dimensions, and 85 components which represent various characteristics in different periods of time. The thesis that women's efficient leadership has an evolving nature was approved and that it consists of a combination of factors such as capability of team making, having vision, cognitive and psychological capabilities, ability to bring continuous improvement of organizational performance, mentoring and making effective relations. In this study, the influence of mentioned factors on women's efficient leadership has been investigated by means of questionnaires and has been approved.
\end{abstract}

Key words: Efficient leadership, factors on women's efficient leadership, women's leadership, compound approach.

\section{INTRODUCTION}

The difference in social status and modes and individuals' expectations from women leads to unfair prejudiced in people's behavior concerning women. From the very beginning of the Prophet's (PBUH) mission Islam offered a new viewpoint regarding women's role in the society, to the extent that counted women's activities inside house as productive activity and considered payment for it. However, up to the second half of the twentieth century neither the Islamic communities nor the other communities attended to this important Islamic principle, and many of the developed countries, especially United States and Canada, that claim they have been the first in the world to promote women's presence in business, management and leadership of organizations neglected it. Since the second half of the twentieth century, through expansion of urbanization, education, communication technology, democracy, and improvement of women's awareness of their status and 
position, they have become more alert about participating in social, economical, cultural, scientific, political affairs and managerial fields (Maleki, 1999).

By advancement of industries and prevalence of business in social life, women were involved in initiating businesses or taking managerial offices in large organizations alongside men and even with much more speed, in a way that according to the statistics women taking managerial offices in large organizations has increased more than $20 \%$ and the number of businesses started by women has increased more than $30 \%$ in the recent past 20 years (US Bureau of Labor Statistics, 1982).

Given this trend, many of the leadership researchers have concluded that female leadership style is more advantageous, thus, female leadership style is more effective than masculine leadership under the new and changing conditions of the world. Having the rise of women in leadership in mind, it is obvious that the prejudices and clichés about women and their role in the society have undergone change and revision. This is not only compatible with freedom and equality of women and men, but as the result of an ideal leadership style has been studied by researchers (Furst and Reeves, 2008).

On the other hand, although leadership has been the focus of the organization researchers for many years, the significant social, political, and economical changes during the last two decades has lead to the discussion of effective leadership gaining importance (Duckett and Macfarlane, 2003). Therefore, the presence of women in organization and using effective leadership styles can promote the function of the organization, and based on this the objective of this paper is to find appropriate answers to the following questions:

1. What is the nature of effective leadership of women?

2. What are the components of female effective leadership style in governmental organizations of the country?

3. How are the relationship and position of each of the components of female effective leadership style in governmental organizations of the country?

4. How important are the components forming the female effective leadership style in governmental organizations of the country?

\section{LITERATURE REVIEW}

\section{Theoretical framework of the paper}

Organizing and starting a case study without having a theoretical framework results in storytelling; therefore, a theoretical framework was considered in order to enrich the report findings, organizing the interviews, collecting and management of the data and not to exercise any research design orientation. The framework was based on the teachings of Effective Leadership of Harvey (2004). The reason for choosing this framework was its comprehensiveness in applying for all variables in the past researches. In this way, the suggested theoretical framework includes the ten main "factors of" vision, perspective, inspiration, group empowerment, team building, deep attraction, coaching, constant improvement of organization performance, concentration on self and others knowledge, establishing effective relationship, and personal and psychological characteristics. In fact, it is believed that all issues related to female effective leadership could be summed up under these eight issues. The said subjects were set as the basis of designing open questions from experts and collecting required data. Although the components of this framework were adjusted after interviews, to avoid describing the phenomenon under study without deep comprehension, we adopted a theoretical framework.

\section{Traditional approach to female leadership in organization}

Many people believe that female leaders in organizations will not be able to meet leadership requirements due to differences with men, and because of the stereotypical beliefs about different characteristics of men and women; it is expected that these beliefs affect the female and masculine leadership style and behavior. In fact, it is assumed that female and masculine leaders adopt leading styles according to the stereotypical beliefs attributed to them (Sczensy et al., 2004). Therefore, they emphasized on masculine characteristics and believed that men can meet effective leadership requirements better (Brown, 1979).

From the very beginning of the mission of the holy prophet of Islam, the women's rights and their high position have been greatly emphasized. Especially, the conduct of ignorant Arabs towards women and girls at that time illuminates the teachings of Islam in this regard, and there have been many discussions on women's rights and position in Islamic jurisprudence and law from the inception of Islam until today; we can refer to the presence of women in critical moments of Islamic history to prove this (Maleki, 1999). In non-Islamic communities only the women of New Zealand had achieved equal political rights by the beginning of twentieth century. Before First World War by conferring equal political rights to the women of Australia, Finland, and Norway, the number of such countries amounted to four. During the period from 1918 to 1939 other 19 countries recognized the political rights of women, Soviet Union (1917), Germany (1918), UK (1919), and United States (1920). The French and Italian women also achieved their rights in the first years after the Second World War, and gradually began to enter managerial areas in different organizations (Maleki, 1999). 
Table 1. Summary of the authors' opinions of traditional female leadership in organization approach (researcher made).

\begin{tabular}{|c|c|}
\hline Researcher & Research findings \\
\hline Chapman $^{1}(1975)$ & $\begin{array}{l}\text { ecause of the stereotypical beliefs about different characteristics of men and women, it is expected that these beliefs affect the female and masculine leadership } \\
\text { tyle and behavior. }\end{array}$ \\
\hline $\begin{array}{l}\text { Eskilson and } \\
\text { Wiley }^{2}(1976)\end{array}$ & $\begin{array}{l}\text { The characteristics of most women are compatible with the expectations of a leader or desired director in an organization. Therefore, it is not possible for most women } \\
\text { to achieve leading position and/or an important position in a managerial hierarchy. }\end{array}$ \\
\hline Brown $^{3}(1979)$ & $\begin{array}{l}\text { Compared to men, the female leaders who have executive activities tend to encourage inter individual relations less. Additionally, it has been proved that compared to } \\
\text { men, women are more concentrated on their tasks (more task oriented). }\end{array}$ \\
\hline $\begin{array}{l}\text { Ashmore } \\
(1986)\end{array}$ & $\begin{array}{l}\text { Women and men have different characters, behaviors, and needs. Different skills have been recognized for men and women. It is believed that men are independent, } \\
\text { realistic, and competitive. On the other hand it is also said that most women are sentimental, affectionate, and passive, these characteristics are evident in the leading } \\
\text { style of men and women. }\end{array}$ \\
\hline $\begin{array}{l}\text { Eagly and } \\
\text { Johnson }^{5}(1990)\end{array}$ & $\begin{array}{l}\text { Women, especially in elite executive positions, tend to show characteristics that are masculine. This occurs especially when female leaders work in a company or } \\
\text { industry where the majority of people are men. }\end{array}$ \\
\hline Senge $^{6}(1990)$ & According to the traditional approach, leadership is defined based on authority and power. In this regard also, men are capable than women. \\
\hline
\end{tabular}

According to the traditional approach, it is believed that female leaders use a more versatile strategy for appointing employees objectives and influencing the team performance in organization. It is also said that women are more conservative and make use of coalition to achieve their goals. In the traditional framework a successful middle manager must have characteristics and attitudes that are more masculine (Chapman, 1975). It is expected that women adopt different behaviors in giving bonus, employee promotion, meet their needs, and they tend to have promotional policies (Catalyst, 2001; Terborg, 1977). This prediction is the basis for traditional female leadership framework. A summary of the authors' opinions is provided in Table 1.

\section{New approach to female leadership in organizations}

With expansion of urbanization, complexity of human relation, growing of literacy rate, explosion of communications and information technology, the tendency to employing women in leading organizations has increased, in a way that it has turned to be the main issue of discussions in directing organizations (Smith, 1997). Since the second half of the twentieth century, especially the last twenty years due to expansion of this mode of management we are witnessing more presence of women in works outside home, specifically in factories, production and trading companies, and gradually women obtained higher levels in the hierarchy of the organizations. According to the statistics of the Bureau of Labor of the United States, women held only $18 \%$ of managerial and administrative positions in the United States in 1982; by 2002 that percentage had increased to $40 \%$. This indicates that women's share has increased by two times during the past 30 years (U.S. Bureau of Labor Statistics, 1982:2002). Eagly and Carli (2003) also indicate that gender gap is being narrowed down and women almost hold half of managerial and administrative positions, and they believe that women are more successful in international economy.
Finally, it is expected by lapse of time a greater number of women take up managerial positions in the organizations; as according to Fortune 500 (500 top US companies ${ }^{6}$ ) in the past decade the number of female directors in the organizations has increased 5 times (Wolfe, 2010).

Women by creating a sense of community, better communication with employees, and listening effectively had better qualifications for acquiring leadership in modern organizations (Eagly and Carli, 2003). In postindustrial societies leaders share power far more and establish many collaborative relationships with the employees. Therefore, contemporary views of effective leadership in organizations encourage teamwork and collaboration and emphasize the ability to empower, support, and engage workers that is congruent with the ways that women lead (Hammer and Chempy, 1994). Women have greater social skills compared to men and are more successful in establishing congeniality. Female leaders, also, are more successful in empowering the employees, and can establish more effective communication and listen 
effectively (Fondas, 1997).

Conlin $^{1}$ (2003), having investigated the schools of thought related to women and organization leadership, argues that due to characteristics and capabilities of female leaders in the organizations many people have attested to the effectiveness of female leading and emphasize that the evident female leadership qualities can be used by men in the organizations to improve the performance and they are not exclusive for women.

To address these issues, researchers must confront the perennially important issue of what behaviors characterize effective leaders. Is it the firm execution of authority over subordinates or the capacity to support and inspire them? And concluding that support and inspiring them leads to effectiveness in organization, they recommend female leadership styles which are congruent with these (Wolfers, 2006; Chemers, 1997).

Vecchio (2002) believes that historically, leadership has been construed as primarily a masculine enterprise, and many theories of leadership have focused on the desirability of stereotypically masculine qualities in leaders. Nevertheless, it is probable that stereotypically feminine qualities of cooperation, mentoring, and collaboration are important to leadership as well, certainly in some contexts and perhaps increasingly in contemporary organizations. He describes female leadership advantages and sees the following items as the reasons for rise in female leadership:

\section{Nowadays women enjoy more awareness and rights} compared to the past.

2. The leading roles and tasks are different from the past.

3. The activities of the organizations have changed.

4. The culture has changed.

Therefore, on the whole it could be concluded that not only the organizations and their leading roles have changed in a way that depend on hierarchy less, but also women have changed due to more freedom in society and higher education in a way that makes them suitable option for leading organizations in modern societies (Smith, 2002). In other words, researchers believe that the effective leading style is more like female leadership style and they believe that female leadership style is more flexible (Rosener, 1995; Helgesen, 1990). Also, Wolfers $^{1}$ (2006) believes that in fact, women tend to cooperation more as to power orientation.

\section{RESEARCH METHODOLOGY}

The present paper is, from the point of view of objective, an applied one. Also, as to the manner of gathering the data (research design), the newness of the concept of female effective leadership and the need to know its nature and quality, explaining the effective components and their relations in the said realm, mixed research was applied. In the qualitative part we collected qualitative data. In the quantitative part we used survey research method.

In the qualitative part of the research the samples are effective
Table 2. Sample volume composition.

\begin{tabular}{lll}
\hline Organizational position & Quantity & Percentage \\
\hline Companies & & \\
\hline Managers and supervisors & 54 & 18 \\
Employees & 253 & 82 \\
Total & 307 & 100 \\
\hline
\end{tabular}

leadership experts. In this paper the expert is the one who has many books about leadership in governmental organizations, taught in university, and has the record of 15 years of serving in a governmental organization. In the quantitative part of the sample all the managers and employees were the object of case study. In qualitative method sampling is limited, and sampling was exercised to the stage of saturation, by preparing a list of the experts by the researchers, then they were called and informed of the topic of the meeting, then meetings were held in their work place or other places and open and half structured interviews were carried out. Finally, 18 people of the experts cooperated in this research and the data were saturated. Then using pair comparative questionnaires the experts' opinions about the definition of the importance and weight of the analyzed components were gathered. In the quantitative part, regarding the limited number of employees and members of the organization under study (the statistical society included 2713 people), the statistical society of the research was obtained equal to 337 according to kokran equation. In this equation measurement error $(\varepsilon)$ which shows the accuracy of estimations was considered 5 percent and assurance level equal to 0.95 , therefore the amount of $(Z)$ will be 1.96 , also in order to maximize the volume of the samples the amounts of $p$ and $q$ were considered 0.5 . The questionnaires were distributed among the chosen people and 307 questionnaires were returned (return rate $91 \%$ ). In the qualitative step the sampling method was purposeful, in a way that a list of all experts was made and they were informed of the time and topic of the meeting. In the quantitative step sampling method is classified random. The number of the sample is provided in Table 2 according to the organizational position.

In the qualitative stage of the research in order to access reliable literature concerning leadership the existing sources on reliable websites were used. Also in qualitative stage data was collected through half structured and open interviews from the experts. As multiple and confirmation sources the documents related to female effective leadership existing in governmental organizations were gathered. In quantitative stage the data was collected from the questionnaires filled by the managers and employees. The measurement scale of the questionnaire was lykert scale 5 that the respondents answered in the scale of complete agreement to complete disagreement. In the qualitative stage the repeatability or reliability of the research was increased by documentation of the data and methods while conducting the plan and using qualitative standard methods and the validity of the research was determined by consulting with experts who have full knowledge of the components of female effective leadership. In the quantitative stage the Cronbach Alpha method was applied in order to calculate the reliability of the measurement tool. The amount Cronbach alpha is 0.96 . It should be noted that the validity of the questionnaire was evaluated by the experts on qualitative stage.

\section{DATA ANALYSIS (RESEARCH FINDINGS)}

In the qualitative stage data analysis was carried out by open and axial coding; some of the codes or in fact the 
themes and concepts were drawn directly from the text of the interviews, and others, in the form of researcher made, were drawn from regarding the themes and concepts drawn from the review of the theoretical basics and leadership and management of women in governmental organizations literature and evidences and findings of the obtained documents (default codes or researcher made codes), and were brought out in the form of current forms in order to reflect the points of the respondents. In the form that according to the described theoretical framework, the subject categories were chosen and after classification and management of the data the default theoretical framework was adjusted and 10 subjects shrank to 7 subjects. Thus, the factors of perspective, insight and inspiration were narrowed down to perspective; the factors of constant group empowerment and team building to ability to team building; the factors of deep attraction and concentration on self and others knowledge to a new factor under the title of cognition power. These classes, which were considered according to the subject coding, were selected from the raised issues for conducting the interviews. After determining the classes or subject codes, we drew out the open codes, which according to the qualitative analysis were directly taken from the sayings of the interviewees, and in fact have direct relation with the sayings of the interviewees. After open coding, in the next step that is through axial coding, we tried to choose main and manifest themes and concepts from among the open codes, to choose those codes that are capable of manifesting and covering other codes and formation of subjects. In fact, if we consider the open codes as minor concepts and themes, the axial codes play the role of general structures or concepts. It should be explained that in this research the analysis and collection of data are done simultaneously in a circular process. The matrix structure of the data analysis and information about the components of female effective leadership in governmental organizations were drawn from the interviews that are shown in Table 3 due to limitation of presenting in the form of subjects, dimensions and components, together with weight and importance of each one of the subjects, dimensions and components.

After finding the components, pair comparison questionnaire was designed to determine the weight and importance of each one of the components, then they were given to the experts and the results were entered into Expert Choice 11 software. The software determined the weight status of each component according to the hierarchy logic. The weight and importance of each component is shown in table 3 . In the quantitative stage the suggested pattern was analyzed using Lisrel software to establish a causal relationship between the independent and dependent variables. In causal patterns, first of all the prototype must be tested, for this purpose different criteria on pattern fitness were used. In this paper also many criteria were used and the results are shown in Table 4. As see in this table all fit indexes confirm the pattern. Generally, if the value of GFI is greater or equal to 0.98 , it indicates suitable fitness of the pattern. On the hand RMSEA must be lower than 0.05 and its confidence interval should not be very much, which is almost 0.035 in this pattern. Moreover, the amounts of NFI, CFI and RFI show the satisfactory level of the pattern, which are greater than 0.9. The CMIN as the most important index for determining fitness was lower than 2 and equal to 1.57 , which is in a suitable domain.

After logically proving the pattern fitness by the data, the meaningfulness of the pattern components and the relations between the variables were evaluated. Generally, the latent variables (the identified factors in the qualitative research) explained 89 percent of dependent variable variance of female effective leadership in the case study. In other words, this pattern shows that 89 percent of the female leadership factors were effective, explain it, and they are identified and 11 percent of the effective factors were not identified. The results of the factor analysis and new factors are provided in Table 5.

\section{Conclusion}

In this part in order to create the possibility of comparing the findings of this paper with the efforts of other researchers which were mentioned before, we can say that in this research unlike most of the previous researches, the maximum meaning of the female effective leadership was considered and the forming measures of female effective leadership was conceptualized operationally. Also, we avoided mere theoretical description of the subject that leads to defected validity. On the other hand the designed pattern is not only about female leadership in organization and can be applied by men, too, that is by nurturing the presented characteristics in this pattern in men, their performance would improve. Many researchers including Rosener $^{1}$ (1995), Helgesen ${ }^{2}$ (1990) and Book ${ }^{3}$ (2000) predict that female leadership can be the supplement of effective leadership for more success of the organization. Therefore, proper answers were provided for the raised questions and assumptions regarding the said issues in the research methodology section of the paper and because of the execution of combined research. Thus, in the qualitative section of the research the components of the pattern were drawn out. To answer the first question of the paper it should be said that seven components of the female effective leadership pattern in the governmental organizations were drawn out.

To answer the second question, it was explained that research too was determined from the default theoretical framework and finally from the adjusted framework in the previous section. In a way that the forming elements of 
Table 3. Components of female effective leadership in governmental organizations (subjects, dimensions and parts).

\begin{tabular}{|c|c|c|}
\hline Component & Dimension & Part \\
\hline \multirow{6}{*}{ Perspective $(0.123)$} & \multirow{6}{*}{$\begin{array}{l}\text { Perspective } \\
(0.243)\end{array}$} & The ability to present a desirable picture of the organization's future among the colleagues \\
\hline & & Recognition of opportunities for organization's growth and development in future among the colleagues \\
\hline & & Knowledge of organization's strategies and making them clear for the employees \\
\hline & & Making the necessity of change in employees \\
\hline & & Knowledge of organization's mission and making them clear for the employees \\
\hline & & The ability to present a desirable picture of the organization's future among the colleagues \\
\hline \multirow{23}{*}{$\begin{array}{l}\text { Team building power } \\
(0.132)\end{array}$} & & $\begin{array}{l}\text { The ability to persuade the managing board of the organization to accept a desirable future for organization } \\
\text { The ability to create common language among the colleagues along with the organization's development in } \\
\text { future }\end{array}$ \\
\hline & & Being optimistic concerning making change and conveying it to the employees \\
\hline & & Inspiring bonus winning for the services and cooperation of the employees \\
\hline & & Creating favorable atmosphere for increasing knowledge and development of individual skills of the employees \\
\hline & & Presenting new ideas for exercising the organization's activities \\
\hline & Inspiration $(0.421)$ & Creating favorable atmosphere for developing individual skills of the employees \\
\hline & & Welcoming the employees' criticism about one's performance \\
\hline & & Encouraging the colleagues to collaborate in change improvement \\
\hline & \multirow{3}{*}{ Holism (0.336) } & The ability to motivate the employees to do activities more than what they did before \\
\hline & & Firm faith in the organization's mission \\
\hline & & The ability to keep a big picture in mind \\
\hline & \multirow{8}{*}{$\begin{array}{l}\text { Constant group } \\
\text { empowerment } \\
(0.343)\end{array}$} & Conferring group bonus to the members of the groups and active and creative units \\
\hline & & Encouraging the colleagues to constant improvement of group collaboration \\
\hline & & Bounding to act according to collaborative leading style \\
\hline & & Creating and enhancing cooperation spirit and coherence among groups of organization \\
\hline & & Boosting the power of decision making power of the group members for improving the group performance \\
\hline & & Identifying and offering constant study opportunities for the colleagues \\
\hline & & The ability to create a creative atmosphere for the employees \\
\hline & & Bestowing adequate power to the groups of organization \\
\hline & \multirow{4}{*}{$\begin{array}{l}\text { Team building } \\
\text { and team work } \\
(0.336)\end{array}$} & The ability to identify the elite and qualified employees \\
\hline & & Attracting the skillful employees to operate the organization's affairs \\
\hline & & Appointing experts in managerial positions \\
\hline & & Appointing capable and acceptable people by the employees for managerial positions \\
\hline
\end{tabular}


Table 3. Contd.

\begin{tabular}{|c|c|c|}
\hline & & Appointing employees according to their specialty in specialized positions \\
\hline & Joint & Encouraging others to move along with the common goal in a team work \\
\hline & & Liking people instead of objects and enhancing managerial collaboration \\
\hline & & The ability to secure the confidence of the employees and board of directors \\
\hline & & Observing justice and fairness when confronted with the problems of the employees \\
\hline & Deep attraction & Having scientific competence in the specialty field of the organization \\
\hline & $(0.143)$ & Having scientific competence in administration of the organization \\
\hline & & Serious efforts to fulfill the objectives of the organization and its growth and development \\
\hline & Being multitask & Understanding the diversities of the organization simultaneously and applying them \\
\hline Cognition (0.194) & $(0.421)$ & Understanding the contradictions of the organization simultaneously and applying them \\
\hline & Social awareness & The ability to influence the employees \\
\hline & $(0.436)$ & Appropriate reaction for identification \\
\hline $\begin{array}{l}\text { Psychological } \\
(0.100)\end{array}$ & $\begin{array}{l}\text { Functionality and } \\
\text { advocating order }\end{array}$ & Trust and commitment \\
\hline & in org. (0.544) & Honesty and trustworthiness in attitude and speech \\
\hline & Leadership & Being prepared to confront power \\
\hline & $(0.465)$ & Having a great deal of perseverance and endurance \\
\hline & Ability of knowing & The ability of knowing oneself and employees \\
\hline & employees & The ability of learning from the experiences and improving oneself and promoting it in organization \\
\hline & & Learning from the successful experiences of the colleagues to improve one's performance \\
\hline Constant improvement & Performance & Constant effort to improve one's professional and job skills \\
\hline $\begin{array}{l}\text { of } \\
\text { performance }(0.112)\end{array}$ & evaluation (0.387) & $\begin{array}{l}\text { Apprehend the importance of using suggestion system and making use of its results to improve one's jog tasks } \\
\text { Planning for constant improvement of performance }\end{array}$ \\
\hline & & Establishing a comprehensive job performance evaluation system to assess the productivity of the colleagues \\
\hline & & Serious efforts to produce high quality products and desirable services \\
\hline & & Making use of the experiences and new methods used by other organizations \\
\hline
\end{tabular}


Table 3. Contd.

\begin{tabular}{|c|c|c|}
\hline & $\begin{array}{l}\text { Constant } \\
\text { improvement } \\
(0.312)\end{array}$ & $\begin{array}{l}\text { Performing active role in fast and effective transfer of new knowledge \& information in the body of the } \\
\text { organization } \\
\text { Constantly identifying the pros and cons of org. performance using the method of knowing the performance } \\
\text { results } \\
\text { Eliminating the discriminations between the colleagues and observing justice and fairness in making decisions } \\
\text { related to the human resources under supervision } \\
\text { Conducting constant and informal assessment and evaluation of the job performance of the colleagues } \\
\text { Empowering for adaptation of the inner changes of the organization with the expectations of the society } \\
\text { Evaluating the performance of the educational groups and different university units }\end{array}$ \\
\hline Coaching (0.187) & Coaching (1.000) & $\begin{array}{l}\text { Creating necessary facilities for the colleagues to access university management } \\
\text { Helping the colleagues to improve their performance } \\
\text { Introducing new thoughts for doing research among the colleagues } \\
\text { Hard work for the growth and progress of the colleagues and nurturing the feeling of self-leadership in them }\end{array}$ \\
\hline \multirow[t]{2}{*}{$\begin{array}{l}\text { Establishing effective } \\
\text { relations }(0.152)\end{array}$} & $\begin{array}{l}\text { Building relations } \\
(0.587)\end{array}$ & Establishing effective and intimate relations \\
\hline & $\begin{array}{l}\text { Conversation } \\
(0.413)\end{array}$ & $\begin{array}{l}\text { Effective listening } \\
\text { Appropriate and flexible speech making } \\
\text { The ability to hear and express the pros and cons of the organization simultaneously }\end{array}$ \\
\hline
\end{tabular}

Table 4. Pattern fitness indexes.

\begin{tabular}{lll}
\hline Index & Acceptable limit & Obtained score \\
\hline CMIN & Lower than 2 & 1.57 \\
RMSEA & Greater/equal to 0.98 & 0.98 \\
CFI & Greater than 0.9 & 0.96 \\
RFI & Greater than 0.9 & 0.98 \\
NFI & Greater than 0.9 & 0.98 \\
\hline
\end{tabular}

the female effective leadership includes 7 subjects, 17 dimensions and 90 parts that show different features in different periods. Meanwhile, in the quantitative stage we investigated the components using confirmatory factor analysis, that the results of factor analysis shows that 89 percent of the factors are influential on the main variable.

To answer the third question, concerning the 
Table 5. Factor analysis results.

\begin{tabular}{llll}
\hline Row & Factor & Variance \% & Accumulated variance \% \\
\hline 1 & Perspective & 13.843 & 13.843 \\
2 & Team building power & 12.027 & 25.87 \\
3 & Cognition power & 14.459 & 40.329 \\
4 & Psychological power & 12.701 & 53.03 \\
5 & Constant improvement of performance & 11.008 & 64.038 \\
6 & Coaching & 12.589 & 76.627 \\
7 & Establishing effective relations & 11.981 & 88.608 \\
\hline
\end{tabular}

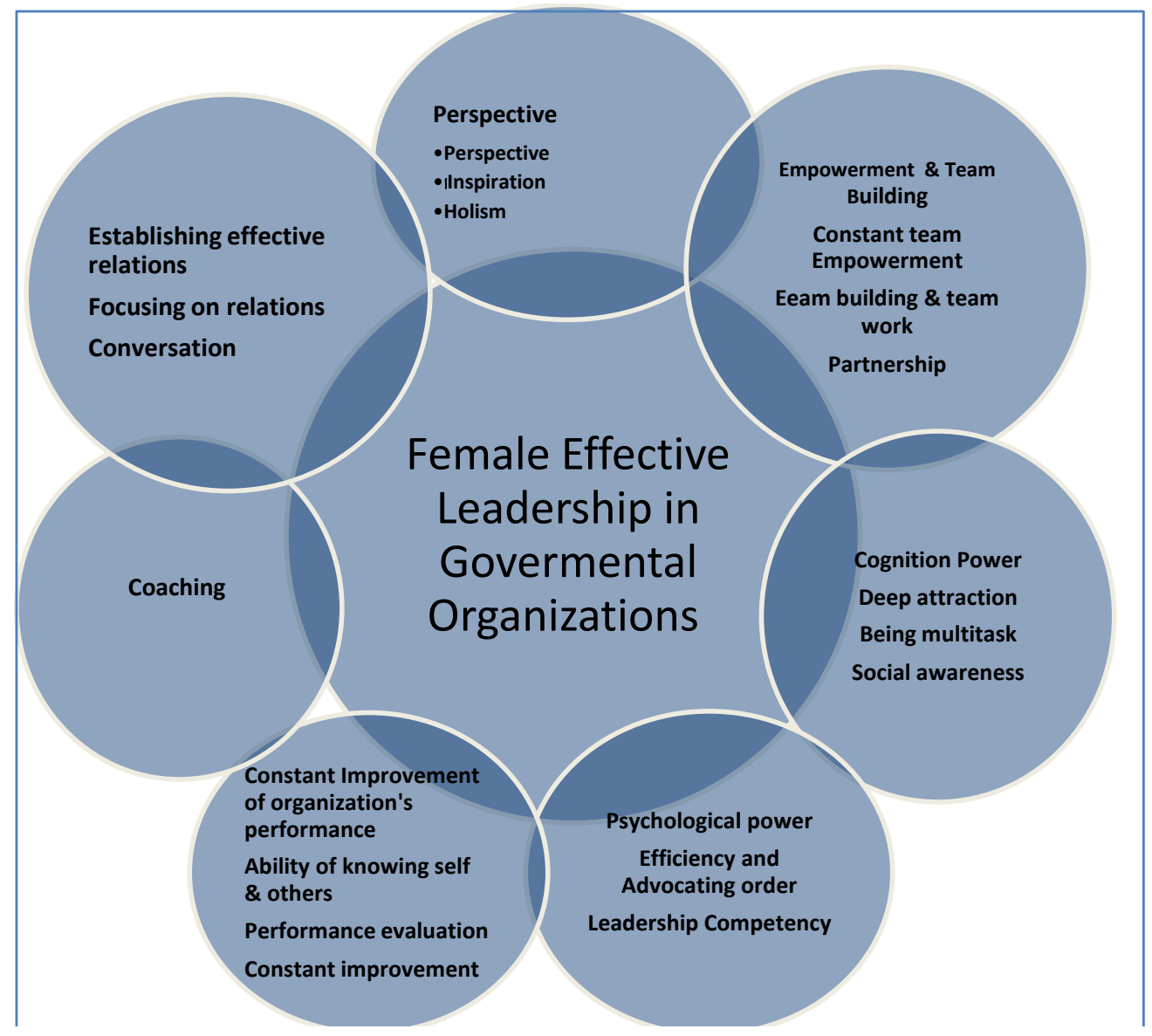

Figure 1. The position of each element in the forming pattern of female effective leadership.

"the position of each element in the forming pattern of female effective leadership" we can illustrate it in a three level pattern as shown in Figure 1. In a way that the first level is the indicator of the subjects, the second level is the indicator of the dimensions and the third level is the indicator of parts. It should be noted that the concepts of each one of the mentioned dimensions in different stages depends on the specific conditions of that period and are manifested in the said parts. However, because of the limitation of illustration of the 90 parts we bring only the first level. To answer the fourth question, we graded and determined the weight and importance of each component in the qualitative stage that the importance and weight of each one of the factors was drawn out by hierarchy analysis and is shown in Table 3.

\section{Suggestions}

In the end given that the present paper is the first study 
on identifying the components of female effective leadership pattern, the following suggestions are offered to develop and deepen this new knowledge:

1. Conducting exploratory researches using other qualitative research strategies;

2. Conducting research on businesses created and managed by women;

3. Exercising the findings of the present research in independent businesses and allowing the possibility of comparison;

4. Exercising the findings of the present research in men's leadership in governmental organizations and allowing the possibility of comparison;

In addition to the said theoretical suggestions, in the end some other practical suggestions for the use of the governmental organizations are offered as follows. It should be noted that the purpose of this paper is to offer a novel pattern of the female effective leadership in the governmental organizations of the country and it seems that this style of leadership is the developed form of effective leadership pattern that the organizations can use according to the global changes. Thus, this style is not exclusive to women and any organization willing to prosper can benefit from it:

1. Boosting these components in women and teaching men to learn them.

2. Supporting female leadership in governmental organizations in order to empower the state organizations.

3. Eliminating the negative atmosphere related to female leadership in governmental organizations.

4. Conferring authority to women in governmental organizations.

5. Extending the office of women as leaders and managers in governmental organizations to benefit from the positive results that bear fruit in long term.

6. Explaining the components of female effective leadership pattern by introducing successful cases in governmental organizations and encouraging managers to make use of this pattern.

\section{REFERENCES}

Ashmore RD, Del Boca FK, Wohlers AJ (1986). The social psychology of female - male relations: A critical analysis of central concepts. Academic Press, 69-119.

Brown M (1979). Male versus female leaders: A comparison of empirical studies: A Comparison of Empirical Studies, no. 5: 45-69.
Catalyst J (2001). Female leadership advantage and disadvantage: Resolving the contradictions. Psychology of Women Quarterly, 2007 . Wiley Online Library.

Chapman JB (1975). Comparison of Male and Female Leadership Styles." Acad. Manage. J. 3: 645-650.

Chemers MM (1997). An integrative theory of leadership. Mahwah, NJ: Erlbaum.

Conlin M (2003). The new gender gap: From kindergarten to grad school, boys are becoming the second sex. BusinessWeek.

Duckett H, Macfarlane E (2003), Emotional Intelligence and Transformational Leadership in Retailing, Leadership Organization Deve. J. 24: 309-317.

Eagly AH, Johnson BT (1990). Gender and Leadership Style: A MetaAnalysis. Psychological Bulletin, no. 111: 3-22.

Eskilson A, Wiley D (1976). Sex composition and leadership in small groups. J. Experimental Ana. Behavior. 13: 243-66.

Fondas N (1997). Feminization unveiled: Management qualities in contemporary writings. Acad. Manage. Rev. 223: 257-282.

Furst A, Reeves M (2008). Queens of the hill: Creative destruction and the emergence of executive leadership of women. Leadership Quart. 19 (3): 372-384.

Hammer M, Champy J (1994). Reengineering the corporation: A manifesto for business revolution. New York: Harper Business.

Harvey (2004) "Leadership Model for Academic Administrative Success" Hampton University Website.

Helgesen S (1990). The female advantage: Women's ways of leadership. New York: Doubleday Currency.

Maleki , N.(1999). The Leadership Behavior of Female Manager in Selected Companies of Metro Manila : An assessment, Manil.

Rosener JB (1995). America's competitive secret: Utilizing women as management strategy. New York: Oxford University Press.

Sczensy S, Bosak J, Neff D, Schyns B (2004). Gender stereotypes and the attribution of leadership traits: A crosscultural comparison. Sex Roles, 51: 631-645.

Senge $P$ (1990). The fifth discipline. New York: Doubleday.

Smith B (2002). Woman and Political Management. New York: PrinticeHall.Fifth Edition.

Terborg JR (1977). Women in management: A research review. Journal of Applied Psychology.

U.S. Bureau of Labor Statistics. (2006).Women in the labor force: A databook. Report 996. Retrieved December 18, 2006 from http://www.bls.gov/cps/ wlf-databook2006.htm

Vecchio RP (2002). Leadership and gender advantage. Leadership Quart. 13: 643-671.

Wolfe L (2010). A Decade of Women CEOs at FORTUNE 500 Companies.

Wolfers J (2006). Diagnosing Discrimination: Stock Returns And CEO Gender ." J. Eur. Econ. Association 4: 531-541. 